\title{
The promise of placental power
}

\author{
Alden H. Harken, MD, FACS
}

From the Department of Surgery, University of California, San Francisco-East Bay, Oakland, Calif.

Disclosures: Author has nothing to disclose with regard to commercial support.

Received for publication March 15, 2017; accepted for publication March 17, 2017; available ahead of print April $14,2017$.

Address for reprints: Alden H. Harken, MD, FACS, Department of Surgery, University of California, San

Francisco-East Bay, 1411 E 31st St (QIC 22134), Oakland, CA 94602 (E-mail: alden.harken@ucsfmedctr.org). J Thorac Cardiovasc Surg 2017;154:541-2

$0022-5223 / \$ 36.00$

Copyright (C) 2017 by The American Association for Thoracic Surgery

http://dx.doi.org/10.1016/j.jtcvs.2017.03.059

We all know that the entire genetic information contained in cells from our heart, our pancreas, and our toe are the same. Different parts of our genome are expressed at different anatomic sites to create a heart or a nose. Organ transplantation has long been stifled by the paucity of donor tissue and the immunologic rejection of foreign antigens. Two decades ago, at the Roslin Institute in Edinburgh, investigators removed the nucleus from an adult lamb's skin cell and transferred it into an empty, unfertilized oocyte (one that had had its nucleus removed). This reprogrammed ovum was then placed into the uterus of a surrogate mother ewe, and months later-voila! Dolly was born. With this technique of somatic cell nuclear transfer, the entire gene map of a patient can be transferred into a carrier oocyte, and the maturing blastocyst can then be transferred into a surrogate mother.

Now, after Uncle Fred's heart attack, he couldn't breathe at night unless he was sitting up. Fred's doctors told him that parts of his heart weren't working, and what he really needed to do was to replace the broken parts of his heart with working cells. Both Fred and his bone marrow cells, however, were old and fragile. Fortunately, Fred's daughter was a nurse in the birthing center at the local hospital. She saw human placentas full of young, vibrant, welcoming stem cells discarded every day. Somatic cell nuclear transfer can be accomplished in animals, including human beings. The ethical firestorm associated with growing cells, tissue, or organs in an ectopic surrogate site for ultimate human transplantation is akin to a megaton nuclear conflagration. Alternatively, human placental tissue, complete with its resident mesenchymal stem cells (MSCs), is readily available. And MSCs by definition do not express rejection-promoting HLA-DR. MSCs also secrete a healthy spectrum of constructive regulatory and trophic factors ${ }^{1}$ and upregulate cardiomyocyte-related genes. ${ }^{2}$

Fred's daughter, and $\mathrm{Li}$ and colleagues ${ }^{3}$ in their article in this issue of the Journal, propose "to evaluate the appropriateness of human placental-derived mesenchymal stem cells (hPD-MSCs) as an alternative cell source for cell therapy for myocardial regeneration." $\mathrm{Li}$ and colleagues ${ }^{3}$

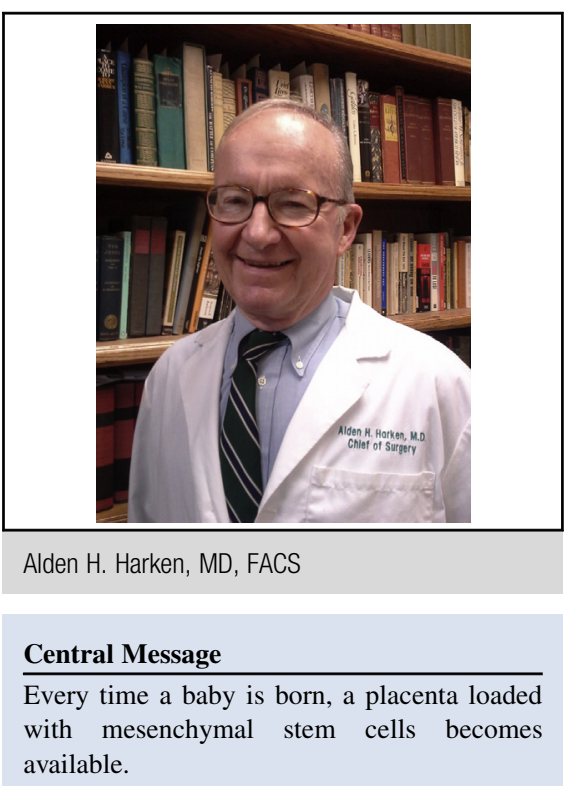

See Article page 543.

characterized hPD-MSCs and compared them with human bone marrow MSCs (hBM-MSCs). They observed that C$\mathrm{X}-\mathrm{C}$ receptor type 4 (CXCR4) was expressed at basal levels in both hPD-MSCs and hBM-MSCs. When stimulated with stromal-derived factor- $1 \alpha$ and induced hypoxia, CXCR4 expression increased in hPD-MSCs more than in hBMMSCs, and the CXCR4-stimulated hPD-MSC population expanded by an order of magnitude while the hBM-MSC population only doubled.

The 4 major current hurdles to cardiac replacement therapy, along with ways in which $\mathrm{Li}$ and colleagues ${ }^{3}$ indicate that hPD-MSCs could help to solve them, are as follows:

1. Availability of donor cells is limited. Placental MSCs are available every time a happy baby is born.

2. Cardiomyocyte cell expansion is limited. Stromal-derived factor- $1 \alpha$ and hypoxia induced expression of CXCR4 on hPD-MSCs, which promoted rapid hPD-MSC expansion.

3. The paracrine environment is hostile. MSCs promote growth and proliferation of neighboring cells through paracrine signaling.

4. The scaffolding to permit survival of functioning cardiomyocytes is lacking. $\mathrm{Li}$ and colleagues ${ }^{3}$ do not address this issue in their article.

This article does not discuss how to build the I-beams that will support the foundation of myocardial tissue engineering. It does, however, persuasively challenge the first 3 of 
these barriers, and it inches Uncle Fred's dream of replacement cardiomyocytes a little closer to fruition.

\section{References}

1. Thakker R, Yang P. Mesenchymal stem cell therapy for cardiac repair. Curr Treat Options Cardiovasc Med. 2014;16:323.
2. Nakanishi C, Yamagishi M, Yamahara K, Hagino I, Mori H, Sawa Y, et al. Activation of cardiac progenitor cells through paracrine effects of mesenchymal stem cells. Biochem Biophys Res Commun. 2008;374:11-6.

3. Li L, Jaiswal PK, Makhoul G, Jurakhan R, Selvasandran K, Ridwan K, et al. Hypoxia modulates cell migration and proliferation in placentaderived mesenchymal stem cells. J Thorac Cardiovasc Surg. 2017;154: 543-52.e3. 